\title{
Analysis of Sustainable Methods to Recover Neodymium
}

\author{
Kalani Periyapperuma ${ }^{1}\left(\mathbb{C}\right.$, Laura Sanchez-Cupido ${ }^{2}\left(\mathbb{D}\right.$, Jennifer M. Pringle ${ }^{1(\mathbb{D}}$ and Cristina Pozo-Gonzalo ${ }^{1, * \mathbb{C}}$ \\ 1 Institute for Frontier Materials, Deakin University, Melbourne, VIC 3125, Australia; \\ mary.periyapperumaachchige@deakin.edu.au (K.P.); jenny.pringle@deakin.edu.au (J.M.P.) \\ 2 Tecnalia, Basque Research and Technology Alliance (BRTA), 20009 San Sebastián, Spain; \\ laura.sanchez@tecnalia.com \\ * Correspondence: cpg@deakin.edu.au
}

Citation: Periyapperuma, K.; Sanchez-Cupido, L.; Pringle, J.M.; Pozo-Gonzalo, C. Analysis of Sustainable Methods to Recover Neodymium. Sustain. Chem. 2021, 2, 550-563. https://doi.org/10.3390/ suschem 2030030

Academic Editor: Matthew Jones

Received: 26 June 2021

Accepted: 31 August 2021

Published: 17 September 2021

Publisher's Note: MDPI stays neutral with regard to jurisdictional claims in published maps and institutional affiliations.

Copyright: (c) 2021 by the authors. Licensee MDPI, Basel, Switzerland. This article is an open access article distributed under the terms and conditions of the Creative Commons Attribution (CC BY) license (https:// creativecommons.org/licenses/by/ $4.0 /)$.

\begin{abstract}
Neodymium (Nd) is one of the most essential rare-earth metals due to its outstanding properties and crucial role in green energy technologies such as wind turbines and electric vehicles. Some of the key uses includes permanent magnets present in technological applications such as mobile phones and hard disk drives, and in nickel metal hydride batteries. $\mathrm{Nd}$ demand is continually growing, but reserves are severely limited, which has put its continued availability at risk. Nd recovery from end-of-life products is one of the most interesting ways to tackle the availability challenge. This perspective concentrates on the different methods to recover $\mathrm{Nd}$ from permanent magnets and rechargeable batteries, covering the most developed processes, hydrometallurgy and pyrometallurgy, and with a special focus on electrodeposition using highly electrochemical stable media (e.g., ionic liquids). Among all the ionic liquid chemistries, only phosphonium ionic liquids have been studied in-depth, exploring the impact of temperature, electrodeposition potential, salt concentration, additives (e.g., water) and solvation on the electrodeposition quality and quantity. Finally, the importance of investigating new ionic liquid chemistries, as well as the effect of other metal impurities in the ionic liquid on the deposit composition or the stability of the ionic liquids are discussed. This points to important directions for future work in the field to achieve the important goal of efficient and selective $\mathrm{Nd}$ recovery to overcome the increasingly critical supply problems.
\end{abstract}

Keywords: neodymium; ionic liquids; electrodeposition; rare earth metals; sustainable; recycling

\section{Introduction}

Rare earth elements (REEs) have attracted substantial research and development attention in recent years, specifically in the fields of metal recovery and recycling from end-of-life devices, due to their limited availability (currently dominated by China) and growing use in various emerging and existing technologies such as rechargeable batteries electric vehicles, wind power plants and advanced electronics. REEs are composed of 15 lanthanides, scandium and yttrium. Based on their atomic number and weight they can be further divided into two subcategories, namely light rare earth elements (LREEsLa to Eu) and heavy rare earth elements (HREEs — the rest of the lanthanides and Y) [1]. Although REEs are relatively abundant in the Earth's crust, they typically occur together in the mineral deposits in low concentrations compared to other more commonly exploited metals (e.g., Fe, Mg, etc.). The similarities in their chemical properties, such as ionic radii, make their separation challenging. The total abundance of REEs in the Earth's crust is estimated as 169 ppm, among which 31 ppm is HREEs and 138 ppm is LREEs [2,3]. Figure 1 shows the distribution of global reserves and mining production along with an overview of the criticality of REEs. 
(a)

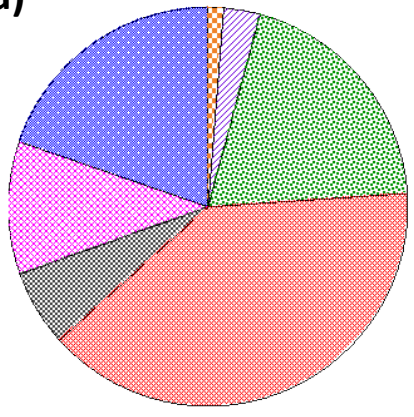

(b)

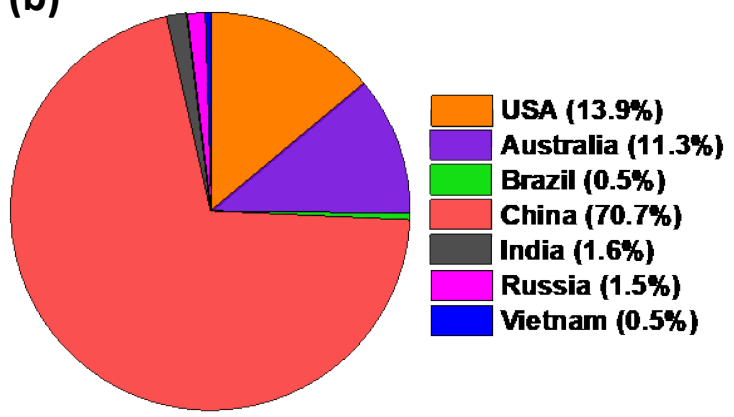

(c)

USA (1.25\%)

Australia (2.96\%)

Brazil (19.71\%)

China (39.43\%)

India (6.18\%)

Russia (10.71\%)

Vietnam (19.71\%)

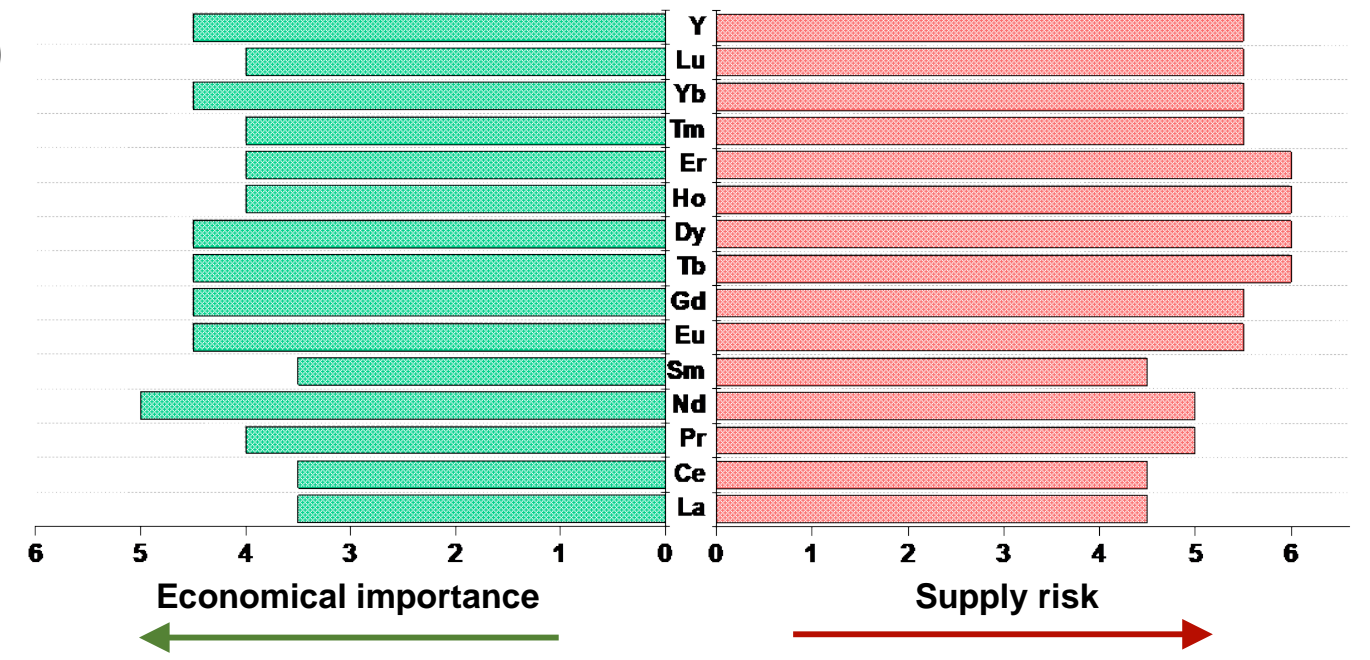

Figure 1. (a) Global REE reserves and (b) global mine production in 2019 [4]. (c) Economic importance and supply risk of REEs (1: non-critical, 6: extremely-critical) [5]. Figures were prepared based on information from $[4,5]$.

As shown in Figure 1a,b, the world's largest REEs reserves are found in China, allowing them to be the largest producer of REEs with a mine production rate higher than $70 \%$ in 2019. The clustering of such a large fraction of natural resources and the production of REEs in a single geographic area may easily lead to a supply risk. As shown in Figure 1c, many REEs are challenged with this risk, while their economic importance continues to grow, especially in permanent magnets as their role is becoming crucial in transition to a green energy technology (e.g., wind turbines and electric vehicles) and economy [1,6].

From a commercial point of view, $\mathrm{Nd}$ is one of the most important REEs due to its application in permanent magnets and rechargeable batteries. In fact, Nd-Fe-B magnets are considered the strongest commercially available permanent magnets [7]. The substantial magnetic field strength per volume of such magnets has enabled their application in a wide range of essential products including electric motors in automobiles, mobile phones, wind turbines, hard disk drives and audio devices. In 2014, the total production of Nd-Fe-B magnets was reported as more than 100,000 tons, with an estimate of $7 \%$ annual increase until 2020, reflecting its substantially growing demand [7-9]. The $\mathrm{Nd}$ content in these magnets can vary from few hundred grams (e.g., $200 \mathrm{~g}$ in $55 \mathrm{~kW}$ electric motor) to $\mathrm{kg}$ (e.g., $175-420 \mathrm{~kg} / \mathrm{MW}$ in direct drive wind turbine) depending on the application [7]. Nd metal has also been used in rechargeable batteries such as nickel metal hydride (Ni-MH) as part of their alloy anode material. Ni-MH batteries also continue to be used in hybrid, plug-in hybrid and electric vehicles. For instance, in 2017 Japan alone reported sales of approximately 166,500 million Ni-MH batteries [10]. The Nd metal content in the alloy anode of a Ni-MH battery is $2.3 \mathrm{wt} \%$ [2] and $10 \%$ of total $\mathrm{Nd}$ produced is used in battery alloy applications [6]. If the present necessity of $\mathrm{Nd}$ metal in automotive and wind turbine applications is representative of future requirement, it is reported that in the absence of 
efficient recovery processes the demand for $\mathrm{Nd}$ will be increased by more than $700 \%$ within the next 15 years [11].

However, exploiting primary mineral sources to meet the increasing demand for $\mathrm{Nd}$ can result in substantial impact on the environment during mining and processing. For instance, the co-extraction of radioactive species such as thorium and uranium together with $\mathrm{Nd}$ raise alarming health and environmental concerns [6]. The necessity to separate and dispose of the radioactive species also creates an added cost to the $\mathrm{Nd}$ recovery process. The extraction and processing of $\mathrm{Nd}$ from primary sources consumes high amounts of energy, water and chemicals [12]. Therefore, the absence of primary deposits in many countries, coupled with health risks and waste generation associated with mining and processing, have the led to an increasingly urgent need for efficient $\mathrm{Nd}$ recovery from secondary sources such as end-of-life products, pre-consumer scraps and industrial residues.

There are number of review articles available on rare earth elements (REEs) recovery using high temperature (named pyrometallurgy, which involves direct melting, electroslag refining, liquid metal extraction and gas phase extraction) and chemically-based recycling methods (named hydrometallurgy and those involving leaching, separation and recovery steps) $[6,13]$. While those methodologies are widely studied, both are still associated with substantial limitations: (1) consumption of large amounts of water and corrosive chemicals; (2) high energy intensity and (3) production of significant amounts of secondary waste $[6,14,15]$. Therefore, from the environmental perspective it is crucial to investigate sustainable approaches to recovering $\mathrm{Nd}$ from secondary sources (end of life products).

Electrodeposition (or electrowinning) is considered to be a promising method of recovery due to its compact plant design, plus the metals can be recovered in their most valuable metallic form. This is a well-established technique used to recover common and non-expensive metals such as $\mathrm{Cu}, \mathrm{Pb}, \mathrm{Ni}$ or $\mathrm{Zn}$ as well as precious metals such as $\mathrm{Ag}$ and $\mathrm{Au}$ from aqueous solutions [16-18]. Molten salts are also a commonly used media to recover $\mathrm{Al}, \mathrm{Ni}$ and precious metal such as $\mathrm{Ti}$ and $\mathrm{Ta}$, but at temperatures above $500{ }^{\circ} \mathrm{C}$ [19-21]. In addition, ionic liquids and deep eutectic solvents have also been used to recover many metals including $\mathrm{Zn}, \mathrm{Ni}, \mathrm{Cu}, \mathrm{Cd}, \mathrm{Cr}, \mathrm{Pd}, \mathrm{Ag}, \mathrm{Pt}, \mathrm{Sb}$ as well as reactive metals such as $\mathrm{Li}$ and $\mathrm{Na}$, which cannot be recovered electrochemically using aqueous media [22-25]. However, electrodeposition or electrowinning for $\mathrm{Nd}$ metal requires further research towards chemically and thermally stable electrolytes to support Nd reduction with reasonable efficiencies. While there are multiple review articles on recycling and recovery of rare earth metals they are mainly focused on conventional hydro- and pyrometallurgy approaches $[2,6,7,26]$.

This perspective provides an overview of current state-of-art recovery methods for $\mathrm{Nd}$ such as hydrometallurgical and pyrometallurgical, as well as the progress on alternative and more sustainable methods such as electrodeposition using ionic liquid electrolytes. The section on hydrometallurgical methods analyses the parameters that enhance the leaching efficiency and purity of the recovered $\mathrm{Nd}$ such as nature and concentration of acids, reaction conditions (temperature, pulp density, stirring conditions), finishing with the pros and cons of the subsequent methods use to recover $\mathrm{Nd}$ (e.g., solvent extraction and precipitation). The section on pyrometallurgy covers molten salt electrolysis, thermal isolation and slag treatment. The state of art on Nd electrodeposition using electrochemically stable media such as ionic liquids (lLs) focuses mostly on model systems using a $\mathrm{Nd}$ salt in an IL. A range of different experimental conditions such as electrolyte composition and electrodeposition conditions (e.g.: potential, temperature and time) are explored in this perspective, and their impact on the Nd electrodeposit quality is reviewed. Finally, future directions for developing an in-depth understanding of this process to achieve an optimised and economically feasible path are also discussed.

\section{Recovery of Nd via Hydrometallurgy}

Hydrometallurgical recycling processes involve the dissolution of materials in acidic or basic reagents, known as leaching, and the subsequent separation and recovery of 
dissolved metals via solvent extraction, selective precipitation, ion exchange and, often, combinations of them. This section focuses on an overview of the leaching processes for $\mathrm{Nd}$ metal recovery from spent $\mathrm{Nd}-\mathrm{Fe}-\mathrm{B}$ magnets and Ni-MH batteries as it is an inherent step in the hydrometallurgical route regardless the subsequent separation or recovery steps.

Prior to the hydrometallurgical process, Nd-Fe-B permanent magnets undergo a demagnetization step via heat treatment. The magnets are then subjected to crushing, grinding and finally sieving, resulting in a fine alloy powder $[27,28]$. Next, during the leaching process, metals from the alloy powder are dissolved using strong inorganic solvents such as hydrochloric acid, nitric acid and sulfuric acid [28]. The performance of the leaching step is usually quantified by means of the leaching efficiency, which refers to the percentage of target metals dissolved from the metals in the total amount of solid leached.

A great deal of research has been focused on investigating strategies to improve the $\mathrm{Nd}$ leaching efficiency, which is considered one of the most important factors in a leaching process. For instance, $\mathrm{Nd}$ leaching efficiency normally increases with the acid concentration and it is dependent on the type of acid used. In general, $\mathrm{H}_{2} \mathrm{SO}_{4}$ acid was found to be the most efficient system, leading to higher $\mathrm{Nd}$ and Dy dissolution and hence higher leaching efficiency, at concentrations from 1 to $3 \mathrm{M}$ [28]. It is also more economic compared to other inorganic acids such as $\mathrm{HCl}$ and $\mathrm{HNO}_{3}$ [28]. In addition, it has been reported that high pulp densities $(150 \mathrm{~g} / \mathrm{L})$, which is defined as the solid to liquid ratio used, result in low leaching efficiency due to the generation of highly viscous solutions [29]. This is detrimental for mass transfer and hence metal dissolution. Application of higher temperatures $\left(75^{\circ} \mathrm{C}\right)$ with optimized pulp density ( $100 \mathrm{~g} / \mathrm{L})$ have led to $98.1 \% \mathrm{Nd}$ recovery efficiency.

Similar phenomena have also been observed in different studies on the leaching of $\mathrm{Nd}$ and other REEs from spent Ni-MH batteries [30]. The application of a higher temperature $\left(75{ }^{\circ} \mathrm{C}\right.$ vs. $20^{\circ} \mathrm{C}$ ) with optimized pulp density $(100 \mathrm{~g} / \mathrm{L})$ have led to improved Nd leaching efficiency from $95.6 \%$ to $98.1 \%$ at same acid concentration $\left(2 \mathrm{M} \mathrm{H}_{2} \mathrm{SO}_{4}\right)$. In that work a mix of rare earths including $\mathrm{Nd}$ was precipitated in the form of the insoluble double sulfate salts $\left(\mathrm{NaNd}\left(\mathrm{SO}_{4}\right)_{2} \cdot \mathrm{H}_{2} \mathrm{O}\right.$ and $\left.\mathrm{NaNd}\left(\mathrm{SO}_{4}\right)_{2}\right)$ as confirmed by the $\mathrm{XRD}$ phase analysis [29]. The precipitate formed hexagonal shaped particles composed of Sm, $\mathrm{Nd}$ and $\mathrm{La}$ among other rare earths. In addition to aforementioned factors, studies with other acids (e.g., $\mathrm{HCl}$ ) have shown that acid concentration and particle size directly influence Nd leaching efficiency. For instance, for a fixed leaching time $(240 \mathrm{~min})$ and temperature $\left(30^{\circ} \mathrm{C}\right)$, by increasing $\mathrm{HCl}$ concentration from 0.05 to $0.3 \mathrm{M}$ or reducing particle size of alloy powders (from 151-180 to 76-105 $\mu \mathrm{m}$ ), Nd leaching efficiency has been increased to $~ 99.9 \%$ in $\mathrm{HCl}$. The latter effect is attributed to the increased active surface area of the smaller particles, which resulted in higher metal dissolution [31].

Organic acids have also been used for Nd leaching processes, reaching promising $\mathrm{Nd}$ efficiencies. For instance, $3 \mathrm{M}$ acetic acid and oxalic acid have been used to achieve approximately $50 \%$ and $44 \% \mathrm{Nd}$ extraction efficiencies, respectively, when leaching was performed at $27{ }^{\circ} \mathrm{C}$, with a pulp density of $20 \mathrm{~g} / \mathrm{L}$, stirring speed of $200 \mathrm{rpm}$ and a particle size of $500 \mu \mathrm{m}$ for $300 \mathrm{~min}$ [28]. However, a higher extraction yield of $99.99 \%$ was reported using acetic acid for the same leaching times with optimized leaching parameters (temperature of $80^{\circ} \mathrm{C}, 0.4 \mathrm{M}$ acetic acid concentration, particle size of 106-150 $\mu \mathrm{m}$ and $10 \mathrm{~g} / \mathrm{L}$ pulp density) [32]. The application of mechanical stirring and the speed of agitation was shown to have a direct influence on Nd extraction efficiency, resulting in an increased yield from $70.29 \%$ to $89.76 \%$ with increasing stirring speed from 200 to $800 \mathrm{rpm}$ due to better dispersion of the sample.

Selective metal leaching is an alternative approach to direct acid leaching that has been proposed for the recovery of $\mathrm{Nd}$ from Ni-MH batteries [33]. This leaching process was considered more beneficial because it can be applied for more concentrated, i.e., high pulp density $(50 \mathrm{~g} / \mathrm{L})$, starting media. In the first step, the cathode powder from the Ni-MH batteries was baked with $\mathrm{H}_{2} \mathrm{SO}_{4}$ acid at $300{ }^{\circ} \mathrm{C}$ to form water soluble sulphates. This solution was then subjected to two stage leaching process where REEs, $\mathrm{Ni}$ and $\mathrm{Zn}$ was recovered in the first stage using just water as the leaching media (at $75^{\circ} \mathrm{C}$ for $1 \mathrm{~h}$ ). A 
second stage leaching was performed using a mixture of $\mathrm{NaHSO}_{3}$ in $\mathrm{H}_{2} \mathrm{SO}_{4}$ (at $95{ }^{\circ} \mathrm{C}$ for $1 \mathrm{~h}$ ) to recover $\mathrm{Co}$ and $\mathrm{Fe}$, due to the low recovery of in this first step. The overall recovery of the metals considering the two steps was $98.2 \% \mathrm{Ni}, 91.4 \% \mathrm{Co}, 98 \% \mathrm{Zn}, 97.8 \% \mathrm{Mn}$ and 96\% rare earth elements (i.e., $\mathrm{La}, \mathrm{Ce}, \mathrm{Nd}, \mathrm{Pr}$ and $\mathrm{Sm}$ ).

In general in hydrometallurgical processes, the dissolved $\mathrm{Nd}$ is recovered by precipitation as fluorides or oxalates, double salts in the specific case of $\mathrm{H}_{2} \mathrm{SO}_{4}$ leachates, and calcined to oxides in some cases [34]. However, the main disadvantage of this precipitation method is that all rare earth metals (REMs) present in the leachate can precipitate together as a mixed product, due to their similar chemical properties, and together with other impurities (e.g., Fe). Solvent extraction technology is an interesting alternative to precipitation that allows the separation of individual rare earths with high purity. This, together with an automated multistage extraction and stripping (also known as back- extraction), make this technique attractive over precipitation [27]. Separation of rare earths via solvent extraction is still under development but the effectivity and feasibility of various types of extractants (e.g., bis-(2-ethylhexyl) phosphoric acid, 2-ethylhexyl-2-ethylhexylphosphonic acid, tetraoctyl digylcol amide, methyltrioctylammonium chloride, amongst others) has been demonstrated $[28,31,35]$. In the solvent extraction process, a rare earth-enriched solution is the final product that can be converted to oxides or salts depending on the chemical composition of the solution.

Nevertheless, one of the main disadvantages of solvent extraction is the large number of steps and the associated consumption of chemicals and waste generation. As an example, some of the most efficient processes proposed to separate and recovery Dy from rare earth concentrates involved more than 50 stages including extraction, stripping and scrubbing [35]. In summary, while hydrometallurgy is commonly applied in the field of metal recovery, it is still problematic for the recovery of $\mathrm{Nd}$ due to the high consumption of water and chemicals and the large number of steps required. The final product is normally in the form of an oxide, rare earth salt mixture (in the case of precipitation) or pure rare earth oxide or salt (in the case of solvent extraction) which have less market value than the metallic state.

\section{Recovery of Nd via Pyrometallurgy}

Pyrometallurgical approaches are another alternative route to recover rare earth metals such as Nd from end-of-life products [15]. The main feature of this process is that they operate at high temperatures, ranging from 500-1000 ${ }^{\circ} \mathrm{C}$. In comparison to hydrometallurgical routes, thermal processing presents some advantageous such as easier scalability, consumption of fewer chemicals and minimized water usage [14,15]. Various pyrometallurgical routes have been employed to recover $\mathrm{Nd}$ from permanent magnets and $\mathrm{Ni}-\mathrm{MH}$ batteries, including molten salt electrolysis, thermal isolation and slag treatment process.

Molten salt electrolysis is commonly used to recover $\mathrm{Nd}$ from permanent magnets using fluoride or chloride-based halide salts. For instance, $\mathrm{Nd}$ metal has been recovered from $\mathrm{Nd}-\mathrm{Fe}-\mathrm{B}$ magnet by a chemical reaction, described below, and then an electrolysis process (electrowinning) using a media composed of $10-64 \mathrm{wt} \%$ of $\mathrm{NdF}_{3}$ in $\mathrm{LiF}$ at $860{ }^{\circ} \mathrm{C}$ in a controlled $\mathrm{O}_{2}$ and $\mathrm{H}_{2} \mathrm{O}$ environment [36]. $\mathrm{NdF}_{3}$ is synthesized by chemically reacting a magnet with $\mathrm{HCl}$ and $\mathrm{NH}_{4} \mathrm{~F}$ followed by heating of the resultant $\mathrm{NdF}_{3}$ at $700{ }^{\circ} \mathrm{C}$ to improve its crystallinity. This approach produces a dense $\mathrm{Nd}$ metal deposit with $99.78 \%$ purity. However, the evolution of harmful gases (e.g., $\mathrm{CF}_{4}$ and $\mathrm{F}_{2}$ ) during electrolysis led to further research on alternative halide salts.

The electrolysis of $2 \mathrm{wt} \% \mathrm{NdCl}_{3}$ in $\mathrm{KCl}-\mathrm{LiCl}$ was considered an alternative to fluoride melts to generate dense $\mathrm{Nd}$ deposits with rectangular shaped particles at a relatively lower temperature, $500{ }^{\circ} \mathrm{C}$ [37]. This was attributed to instantaneous nucleation mechanism resulting in uniform aggregation and thus densely packed nuclei [38]. However, the severe extent of the oxidation reaction from $\mathrm{Nd}$ metal to $\mathrm{NdOCl}$ is a major issue in the use of $\mathrm{KCl}-\mathrm{LiCl}$ melts [37]. Molten $\mathrm{MgCl}_{2}$ and $\mathrm{Mg}$ metal have also been used for the extraction and recovery of $\mathrm{Nd}$ from $\mathrm{Nd}-\mathrm{Fe}-\mathrm{B}$ magnet scraps. The extraction process was performed 
at temperatures as high as $1000{ }^{\circ} \mathrm{C}$ to achieve optimum $\mathrm{Nd}$ recovery efficiencies $(87 \%$ for $\mathrm{MgCl}_{2}$ melts and $\sim 100 \%$ for molten $\mathrm{Mg}$ ) $[39,40]$ by improving the mass transport properties and reaction kinetics at high temperatures.

As previously mentioned, thermal isolation is another pyrometallurgical approach used to recover $\mathrm{Nd}$ (in the oxide form) from both spent magnets and $\mathrm{Ni}-\mathrm{MH}$ batteries. This is a two-step process where the waste material is first oxidized at $1000{ }^{\circ} \mathrm{C}$ for $60 \mathrm{~min}$ followed by a selective reduction reaction at temperatures between $1400-1550{ }^{\circ} \mathrm{C}$ [41-43]. For Nd-Fe-B magnets, carbon based reducing agents such as graphite and waste tyre rubber-derived carbon (WTR-DC) materials have been investigated [41,42]. Although similar $\mathrm{Nd}$ recovery efficiencies have been reported with both reducing agents (66.4 vs. $64.2 \%$, respectively), the WTR-DC based reduction process had the advantage of generating less solid carbon residue compared to graphite. For spent Ni-MH batteries, Fe rich ( $>99 \%)$ reducing agents developed from waste electronics have been studied [43] and successful recovery of $10 \mathrm{wt} \% \mathrm{Nd}, 47 \mathrm{wt} \% \mathrm{La}, 25 \mathrm{wt} \% \mathrm{Ce}$ and $5 \mathrm{wt} \% \mathrm{Pr}$ as oxides was demonstrated.

In addition to these processes, slag treatment has also been employed to recover REEs from spent $\mathrm{Ni}-\mathrm{MH}$ batteries. Various slag systems such as $\mathrm{CaO}-\mathrm{CaF}_{2}, \mathrm{CaO}-\mathrm{SiO}_{2}-\mathrm{MgO}$ and $\mathrm{SiO}_{2}-\mathrm{Al}_{2} \mathrm{O}_{3}-\mathrm{MnO}$ have been melted with spent battery materials at high temperatures $\left(>1500{ }^{\circ} \mathrm{C}\right)$ to yield a Ni-Co alloy and a slag phase enriched with rare earth oxides [44,45]. However, this approach is more challenging as the use of such stable oxides introduces additional impurities to the system and it requires further processing to separate REEs from the slag phase.

In summary, although pyrometallurgical processes are capable of successful recovery of Nd from end-of-life products while overcoming the key drawbacks of hydrometallurgical routes, they lead to different challenges including significant energy consumption, safety issues and negative environmental consequences (e.g., toxic gas emission) due to the use of extremely high operating temperatures. In addition, the requirement for further processing steps to separate individual REEs is also problematic. These substantial drawbacks drive an urgent need to further investigate $\mathrm{Nd}$ recovery processes that are more sustainable and environmentally friendly.

\section{Recovery of Nd via Electrodeposition}

Electrochemical deposition is a promising alternative to recover $\mathrm{Nd}$ metal owing to mild working temperatures, compact design of the equipment required, and the smaller amount of chemicals needed in comparison with pyrometallurgical and hydrometallurgical methods. Those factors are beneficial to dramatically reduce the environmental footprint. $\mathrm{Nd}$ metal electrodeposition undergoes either a one-step $\left(\mathrm{Nd}^{3+}+3 \mathrm{e}^{-} \rightarrow \mathrm{Nd}^{0}\right)$ or a two-step $\left(\mathrm{Nd}^{3+}+\mathrm{e}^{-} \rightarrow \mathrm{Nd}^{2+}\right.$, and $\left.\mathrm{Nd}^{2+}+2 \mathrm{e}^{-} \rightarrow \mathrm{Nd}^{0}\right)$ cathodic process [46,47]. The use of molten salts for $\mathrm{Nd}^{3+}$ electrolysis has been reported in the literature [47-50], however it is highly energy demanding and corrosive in nature. Therefore, other non-aqueous solvents have been investigated to accommodate the high negative potential of $\mathrm{Nd}^{3+} / \mathrm{Nd}^{0}$ redox reaction $(-2.41 \mathrm{~V}$ vs. SHE). Understanding the influence of parameters such as electrodeposition potential, temperature, solvent, and electrolyte composition is necessary to develop high quality $\mathrm{Nd}$ deposits from waste solutions. Therefore, these parameters are discussed in detail in this section. The studies that have been discussed here use model electrolyte systems prepared by dissolving a $\mathrm{Nd}$ salt in the solvent of interest unless otherwise mentioned. This is a common approach used in the literature prior to investigating $\mathrm{Nd}$ recovery under real life conditions.

The potential suitability of organic solvents such as dimethyl sulfoxide (DMSO) was studied using $\mathrm{NdCl}_{3}$ salt, where different electrolysis parameters including electrolysis mode, supporting electrolyte, $\mathrm{Nd}^{3+}$ concentration, temperature and stirring were analysed to understand their impact on $\mathrm{Nd}$ electrodeposition [51]. The application of a pulsed current or voltage was concluded to be favourable compared to traditional galvanostatic or potentiostatic polarisation as this resulted in increased mass deposited ( $3 \mathrm{vs} .12 \mathrm{mg}$ ) and higher purity of the $\mathrm{Nd}$ metal electrodeposit. Larger electrodeposits have also been 
obtained by increasing the $\mathrm{Nd}^{3+}$ concentration (12 vs. $19 \mathrm{mg}$ deposits obtained from $0.1 \mathrm{vs}$. $1 \mathrm{M} \mathrm{NdCl}_{3}$, respectively) and the introduction of stirring conditions (19 vs. $21 \mathrm{mg}$ deposits obtained from $1 \mathrm{M} \mathrm{NdCl}_{3}$ without or with stirring, respectively) at $30^{\circ} \mathrm{C}$. Temperatures above $50{ }^{\circ} \mathrm{C}$ were found to be detrimental due to the occurrence of side reactions that resulted in less pure deposits.

Room temperature ionic liquids (RTILs, Table 1) are promising alternatives to organic solvents for $\mathrm{Nd}$ electrodeposition mainly due to their superior electrochemical stability that is required to recover reactive metals with high negative potentials [52,53]. Other RTILs properties such as thermal stability, negligible vapour pressure and non-flammability are highly desirable for metal electrowinning [54]. Their application in Nd electrolysis has been investigated using a model system of Nd salt dissolved in a neat IL. Thus far, ILs composed of fluorinated anions and ammonium, phosphonium or pyrrolidinium cations have been studied. Nd electrodeposition has been most investigated in phosphonium ILs, such as [ $\left.\mathrm{P}_{2225}\right][\mathrm{TFSI}$ (triethylpentylphosphonium bis(trifluoromethylsulfonyl)imide) and $\left[\mathrm{P}_{66614}\right][$ TFSI] ((trihexyltetradecylphosphonium) TFSI) at temperatures between 75 and $150{ }^{\circ} \mathrm{C}[55,56]$. Ammonium ILs such as [ $\left.\mathrm{N}_{1114}\right][\mathrm{TFSI}$ (trimethylbutylammonium TFSI) and [DEME][TFSI] ( $N, N$-diethyl- $N$-methyl- $N$-(2-methoxyethyl)ammonium TFSI) have also been successfully used for $\mathrm{Nd}$ electrodeposition at room temperature and $80{ }^{\circ} \mathrm{C}$, respectively [57,58]. In contrast, almost no deposit was obtained from [ $\mathrm{N}_{1116}$ ][TFSI] (trimethylhexylammonium TFSI) [55], which was attributed to the higher viscosity and stronger interactions between ammonium cation and [TFSI $]^{-}$compared to that with the phosphonium cation. However, the different $\mathrm{Nd}$ sources used (i.e., $\mathrm{Nd}\left(\mathrm{NO}_{3}\right.$ vs. $\left.\mathrm{Nd}(\mathrm{TFSI})_{3}\right)$ and the higher salt concentration ( $0.5 \mathrm{M}$ vs. $0.06 \mathrm{M}$ in [ $\left.\mathrm{N}_{1116}\right]$ [TFSI]) could also play a role due to their effect on $\mathrm{Nd}^{3+}$ speciation affecting the electrodeposition process $[55,59]$.

Successful Nd electrodeposition has also been achieved using neutral ligand ILs, synthesised by dissolving a $\mathrm{Nd}$ salt (e.g., $\mathrm{Nd}(\mathrm{TFSI})_{3}$ ) in a neutral ligand such as trimethyl phosphate (TMP) or dihexyloctanamide (DHOA) leading to an ionic liquid with the following form: $\left[\mathrm{Nd}(\text { ligand })_{\mathrm{x}}\right]^{3+}\left[(\mathrm{TFSI})_{3}\right]^{3-}[60,61]$. The $0.17 \mathrm{~mol}^{-1} \mathrm{Nd}(\mathrm{TFSI})_{3}$ in the TMP-based system resulted in a $-2 \mathrm{~mA} \mathrm{~cm}^{-2} \mathrm{Nd}^{3+}$ reduction peak current density (a parameter related to the extent of neodymium electrodeposition) at room temperature while the DHOA based IL suffered from lower solubility $\left(0.1 \mathrm{~mol} \mathrm{l}^{-1} \mathrm{Nd}(\mathrm{TFSI})_{3}\right)$ and 10 times lower reduction peak current density $\left(-0.2 \mathrm{~mA} \mathrm{~cm}^{-2} \mathrm{Nd}^{3+}\right)$ at higher temperature, $80^{\circ} \mathrm{C}$. As an alternative to the costly [TFSI] $]^{-}$based salts, $0.05 \mathrm{M}$ neodymium oxide has also been dissolved in DHOA for electrodeposition studies [60]. However, further studies are required to investigate the quality of the electrodeposit, such as $\mathrm{Nd}$ oxidation state and purity.

Neutral ligands such as $N, N, N^{\prime}, N$-tetraoctyldiglycolamide (TODGA) and tri- $N$-butylphosphate (TBP) dissolved in $\left[\mathrm{P}_{2225}\right][\mathrm{TFSI}]$ have been also studied as $\mathrm{Nd}^{3+}$ electrodeposition media. The neutral ligand $/\left[\mathrm{P}_{2225}\right][\mathrm{TFSI}] \mathrm{IL}$ mixtures were first used to selectively extract $\mathrm{Nd}^{3+}$ from real leachates, which contained impurities such as iron.

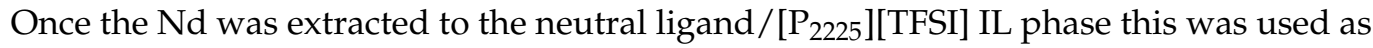
electrolytic media to successfully deposit $\mathrm{Nd}$ at $100{ }^{\circ} \mathrm{C}[59,62]$.

Amongst all the IL compositions studied, phosphonium based electrolytes have been the ones studied in most detail. The electrochemical behaviour of $\mathrm{Nd}^{3+}$ in phosphonium IL electrolytes was found to be influenced by various factors including temperature, deposition potential, impurities, $\mathrm{Nd}^{3+}$ concentration and speciation, and additives such as $\mathrm{H}_{2} \mathrm{O}$. For instance, when increasing the temperature of $0.5 \mathrm{M} \mathrm{Nd}(\mathrm{TFSI})_{3}$ in [ $\mathrm{P}_{2225}$ ][TFSI] electrolyte from 50 to $105^{\circ} \mathrm{C}$, the cathodic potential shifted to more positive values, indicating an easier $\mathrm{Nd}^{3+}$ reduction [55]. However, the effect of temperature on the quality and quantity of the electrodeposit is yet to be determined. 
Table 1. Structures and chemical names of different ionic liquid ions used in the electro-recovery of $\mathrm{Nd}$.

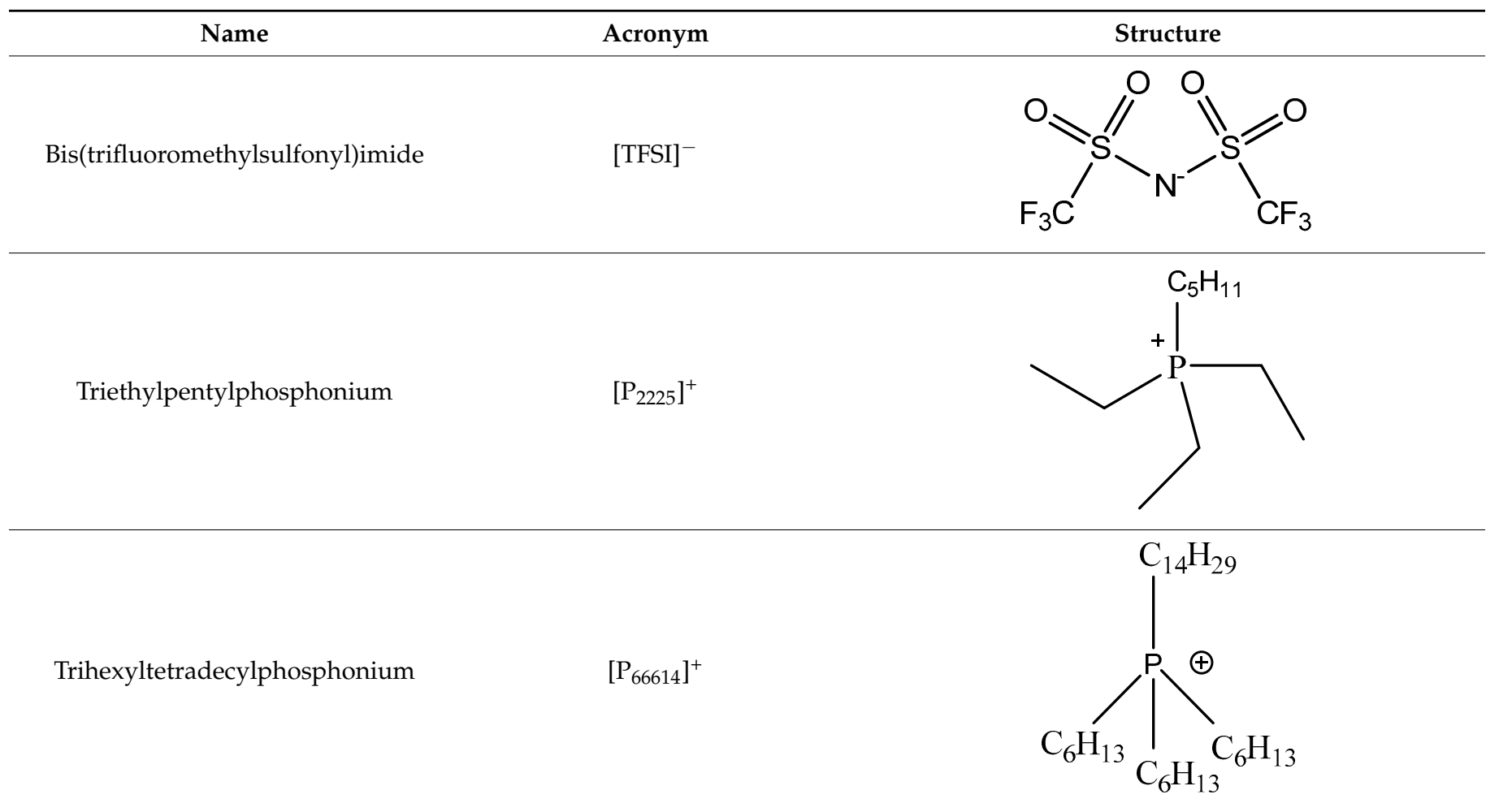

Trimethylbutylammonium $\quad\left[\mathrm{N}_{1114}\right]^{+}$

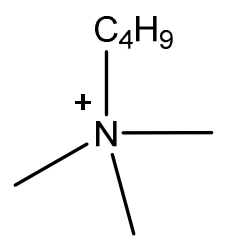

$\mathrm{N}, \mathrm{N}$-diethyl-N-methyl-N-(2methoxyethyl)ammonium

$\left.{ }_{[\mathrm{DEME}}\right]^{+}$

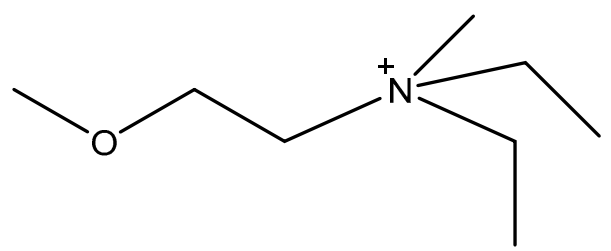

Trimethylhexylammonium

$\left[\mathrm{N}_{1116}\right]^{+}$
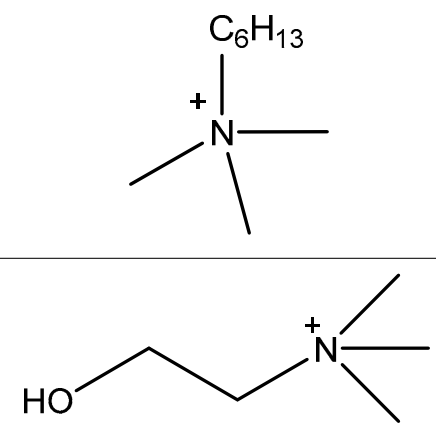

The applied electrodeposition potential has also been shown to have a direct impact on the $\mathrm{Nd}$ nucleation mechanism and the subsequent deposit composition. For example, the reduction of $\mathrm{Nd}^{3+}$ in [DEME][TFSI] ([DEME] $=N, N$-diethyl- $N$-methyl-N(2-methoxyethyl)ammonium) IL electrolyte has been shown to follow an instantaneous nucleation mechanism at $-3.4 \mathrm{~V}$ vs. $\mathrm{Ag} / \mathrm{Ag}^{+}$, whereas progressive nucleation mechanism behaviour was evident at more negative potentials $(-3.5$ and $-3.6 \mathrm{~V})$ [58]. This is 
important as it led to a higher nuclei density at $-3.4 \mathrm{~V}$ and the resultant electrodeposits had distinct compositions, with a higher oxide content evident in the deposit produced at more negative potentials. This demonstrates that the applied potential can be an important parameter to achieve the desired deposit morphology (i.e., dense and compact deposit) and quality.

It is also vital to investigate the electrodeposition of $\mathrm{Nd}$ in the presence of impurities such as transition metals that are often present in the end-of-life products (Nd-Fe-B magnets and $\mathrm{Ni}-\mathrm{MH}$ batteries), as they can directly impact the $\mathrm{Nd}^{3+}$ reduction process and the quality and quantity of the electrodeposit. However, little to no information is available in literature regarding such research. For instance, Ishii et al. reported the recovery of a blend of $\mathrm{Nd}$ and Dy from magnet waste (i.e., in the presence of Fe) using a mixture of ILs composed of [Ch][TFSI] ( $\mathrm{Ch}=2$-hydroxyethyltrimethylammonium) and [P 2225 ][TFSI] [63]. This was achieved through a 2-step selective electrodeposition process where Fe was first deposited on to a $\mathrm{Cu}$ substrate at $150{ }^{\circ} \mathrm{C}$ followed by the $\mathrm{Nd}$ and Dy blend. The electrodeposit from the first step mainly consisted of iron, with less than $1 \%$ of REMs. Therefore, further studies are still required to develop an in-depth understanding on the conditions required to achieve optimum $\mathrm{Nd}$ recovery and highly pure electrodeposits in the presence of common impurities. The understanding and impact of the electrodeposition processes' tolerance for impurities that can follow through from the preceding separation steps could simplify the recovery process steps.

In the $\mathrm{Nd}^{3+}$ electrodeposition process, achieving a high cathodic current density is important to increase the amount of $\mathrm{Nd}$ metal recovered. Introduction of an additive such as $\mathrm{H}_{2} \mathrm{O}$ or a co-solvent to the IL electrolyte can improve the mass transport properties and may alter the $\mathrm{Nd}^{3+}$ speciation environment, resulting in changes to the cathodic current density. However, the addition of $\mathrm{H}_{2} \mathrm{O}$ has shown to have different effects in [ $\mathrm{P}_{2225}$ ][TFSI] and [ $\left.\mathrm{P}_{66614}\right][\mathrm{TFSI}]$, the phosphonium ILs in which $\mathrm{Nd}^{3+}$ can be successfully reduced. When the $\mathrm{H}_{2} \mathrm{O}$ content in a $0.5 \mathrm{M} \mathrm{Nd}(\mathrm{TFSI})_{3}$ in $\left[\mathrm{P}_{2225}\right.$ [TFSI] electrolyte was increased from $<100 \mathrm{ppm}$ to approximate $2000 \mathrm{ppm}$, the $\mathrm{Nd}$ deposition potential shifted to more negative values and the cathodic current density decreased ( -0.32 to $-0.18 \mathrm{~mA} \mathrm{~cm}^{-2}$ ) [64]. This was suggested to be due to the formation of $\mathrm{Nd}^{3+}$ complexes with $\mathrm{H}_{2} \mathrm{O}$ that are relatively strongly coordinated compared to that with [TFSI $]^{-}$, thus hindering $\mathrm{Nd}$ deposition. However, a three-fold increase in current density (to ca. $-5 \mathrm{~mA} \mathrm{~cm}^{-2}$ ) has been reported upon increasing the $\mathrm{H}_{2} \mathrm{O}$ content from 0.1 to $0.4 \mathrm{wt} \%$ in $0.1 \mathrm{~mol} \mathrm{~kg}^{-1} \mathrm{Nd}(\mathrm{TFSI})_{3}$ in [ $\left.\mathrm{P}_{66614}\right]$ [TFSI] IL electrolyte [56]. This distinctly different behaviour could be related to the different lengths of the IL cation alkyl chain, ultimately altering the solvation of $\mathrm{Nd}^{3+}$ and the interfacial structure on the electrode [56,65-67].

The addition of $\mathrm{H}_{2} \mathrm{O}$ to [ $\left.\mathrm{P}_{66614}\right][$ TFSI] IL electrolyte has also been shown to have a direct impact on the quantity of $\mathrm{Nd}$ deposit, with a more abundant and continuous electrodeposit produced with higher $\mathrm{H}_{2} \mathrm{O}$ content [56]. Surface characterisation of the electrodeposits resulting from the $\left[\mathrm{P}_{66614}\right][\mathrm{TFSI}] \mathrm{IL}$ electrolytes showed the presence of metallic $\mathrm{Nd}$ as well as its oxide and fluoride species. However, further studies are imperative to understand the effect of the amount of $\mathrm{H}_{2} \mathrm{O}$ present in the electrolyte on the quality of the electrodeposit and to quantify the deposit composition.

Increasing the active species concentration, i.e., $\mathrm{Nd}^{3+}$, is also considered to be a possible approach to achieving high cathodic current densities. However, this has only been investigated in the $\left[\mathrm{P}_{66614}\right][\mathrm{TFSI}]$ system, where detrimental results (i.e., a decrease in cathodic current) were observed with increasing the $\mathrm{Nd}(\mathrm{TFSI})_{3}$ concentration from 0.1 to $0.5 \mathrm{~mol} \mathrm{~kg}^{-1}$ [65]. This effect was attributed to the differences in $\mathrm{Nd}^{3+}$ co-ordination environment (i.e., cis/trans and mono/bidentate) and physicochemical properties of the electrolyte (i.e., increased viscosity and low mass transport rate) at high $\mathrm{Nd}^{3+}$ concentrations. This again suggests that the solvation environment of $\mathrm{Nd}^{3+}$ is a key factor in determining its reduction capability and the nature of the resultant electrodeposit. Table 2 provides a further summary of the aforementioned studies. 
Table 2. Electrolyte composition and the resultant electrochemical results of recent electrodeposition studies.

\begin{tabular}{|c|c|c|c|c|c|c|}
\hline Ionic Liquid & Nd Salt & {$\left[\mathrm{Nd}^{3+}\right]$} & Temp. $\left({ }^{\circ} \mathrm{C}\right)$ & $\begin{array}{l}\text { Scan Rate } \\
\left(\mathrm{mV} \mathrm{s}^{-1}\right)\end{array}$ & $\begin{array}{c}j_{\text {peak reduction }} \\
\left(\mathrm{mA} \mathrm{cm}^{-2}\right)\end{array}$ & Ref. \\
\hline$\left[\mathrm{C}_{4} \mathrm{mpyr}\right][\mathrm{TFSI}]$ & $\mathrm{Nd}\left(\mathrm{NO}_{3}\right)_{3}$ & $0.06 \mathrm{M}$ & 25 & 20 & -4 & [57] \\
\hline \multirow{4}{*}[\mathrm{P}_{2225}]{$[$ TFSI] } & \multirow{4}{*}{$\mathrm{Nd}(\mathrm{TFSI})_{3}$} & \multirow{4}{*}{$0.5 \mathrm{M}$} & 50 & \multirow{4}{*}{100} & $-0.25 \times 10^{-4}$ & \multirow{4}{*}{ [55] } \\
\hline & & & 75 & & $-0.35 \times 10^{-4}$ & \\
\hline & & & 90 & & $-0.4 \times 10^{-4}$ & \\
\hline & & & 105 & & $-0.4 \times 10^{-4}$ & \\
\hline \multirow{2}{*}[\mathrm{P}_{2225}]{$[$ TFSI] } & \multirow{2}{*}{$\mathrm{Nd}(\mathrm{TFSI})_{3}$} & \multirow{2}{*}{$0.05 \mathrm{M}$} & 90 & \multirow{2}{*}{2} & -0.12 & \multirow{2}{*}{ [68] } \\
\hline & & & 100 & & -0.15 & \\
\hline DMSO & $\mathrm{NdCl}_{3}$ & $0.1 \mathrm{M}$ & R.T. & 20 & -2 & [51] \\
\hline [DEME][TFSI] & $\mathrm{Nd}(\mathrm{TFSI})_{3}$ & $0.5 \mathrm{M}$ & 80 & 10 & -0.8 & [58] \\
\hline $\begin{array}{c}{\left[\mathrm{P}_{66614}\right][\mathrm{TFSI}]+} \\
0.4 \mathrm{wt} \% \mathrm{H}_{2} \mathrm{O}\end{array}$ & $\mathrm{Nd}(\mathrm{TFSI})_{3}$ & $0.1 \mathrm{~m}$ & 75 & 100 & -5 & [56] \\
\hline$\left[\mathrm{N}_{1114}\right][\mathrm{TFSI}]$ & $\mathrm{Nd}\left(\mathrm{NO}_{3}\right)_{3} \cdot \mathrm{H}_{2} \mathrm{O}$ & $0.06 \mathrm{M}$ & 25 & 20 & -5 & [57] \\
\hline$\left[\mathrm{C}_{4} \mathrm{mpyr}\right][\mathrm{DCA}]$ & $\mathrm{Nd}(\mathrm{TFSI})_{3}$ & $0.03 \mathrm{M}$ & 25 & 100 & $\begin{array}{c}-0.1(+\mathrm{IL} \\
\text { reduction) }\end{array}$ & [69] \\
\hline$\left[\mathrm{P}_{66614}\right][\mathrm{DCA}]$ & $\mathrm{Nd}(\mathrm{OTf})_{3}$ & $0.1 \mathrm{~m}$ & 75 & 10 & -0.25 & [70] \\
\hline$\left[\mathrm{C}_{4} \mathrm{mpyr}\right][\mathrm{DCA}]$ & $\mathrm{Nd}(\mathrm{OTf})_{3}$ & $0.2 \mathrm{~m}$ & 50 & 100 & -12 & \\
\hline$\left[\mathrm{C}_{4} \mathrm{mpyr}\right][\mathrm{DCA}]$ & $\mathrm{Nd}\left(\mathrm{NO}_{3}\right)_{3} \cdot 6 \mathrm{H}_{2} \mathrm{O}$ & $0.2 \mathrm{~m}$ & 50 & 100 & -38 & {$[7 / 1]$} \\
\hline
\end{tabular}

In summary, while phosphonium ILs with the [TFSI $]^{-}$anion have given promising results for the recovery of $\mathrm{Nd}$ through the more benign electrodeposition approach, the work thus-far also suggests that further tuning of the $\mathrm{Nd}^{3+}$ solvation and speciation can further optimise the recovery process and establish a more sustainable and efficient system.

\section{Remarks and Future Suggestions}

Hydrometallurgy and pyrometallurgy have been widely studied for the recovery of rare earths from end-of-life products achieving good recovery efficiencies. However, those methods face a series of challenges such as the need for a large number of steps and extraction/separation techniques for their individual separation, and significant footprint related to the volume of chemicals and high temperatures required. Previous work has successfully demonstrated the promise of electrodepositing $\mathrm{Nd}$ metal using ionic liquid electrolytes. However, to develop an economically feasible process several aspects should be studied and optimized. For instance, the ILs with fluorinated anions that have been studied so far, while successful, present significant challenges including their high cost, poor solubility of $\mathrm{Nd}$ sources (e.g., oxides, nitrates) and environmental impact. Fluorinated ILs show a higher risk of persistence due to their resistance to biotic and abiotic degradation resulting in high ecotoxicity [72-74]. Also, if decomposed, they can produce harmful gases (e.g., HF) [75] detrimentally affecting the environment [76].

Therefore, to establish more sustainable approaches for $\mathrm{Nd}$ electrodeposition, it is imperative to explore non-fluorinated ILs that are ideally cost effective and compatible with commercially accepted operational conditions (e.g., high active species concentration, moisture stable and can result in high $\mathrm{Nd}$ deposition rates). One interesting candidate is the dicyanamide anion based ILs, which are relatively low cost due to their existing application in other industries [77]. We recently reported successful electrodeposition of $\mathrm{Nd}$ from $\mathrm{N}$-butyl- $\mathrm{N}$-methylpyrrolidinium dicyanamide IL electrolyte at relatively low temperatures $\left(50^{\circ} \mathrm{C}\right)$ under less controlled environments $\left(0.15-4.6 \mathrm{wt} \% \mathrm{H}_{2} \mathrm{O}\right)$ [71]. Similarly, it could be interesting to explore ILs based on phosphorus anions (e.g., phosphite, phosphonate) $[78,79]$ or hydrogen sulphate containing anions [80-82], which are considered some of the lowest 
cost ILs and have shown evidence for successful electrodeposition of other metals (e.g., $\mathrm{Cu}, \mathrm{Ag}$ ) [81,83], although the electrochemical stability for $\mathrm{Nd}$ deposition still needs to be assessed.

The use of non-fluorinated ILs will also avoid the formation of undesired Nd-F products that will otherwise decrease the Nd recovery efficiency by passivating the electrode surface and devalue the recovered Nd content. Most of the prior studies that succeeded in the electrodeposition of $\mathrm{Nd}$ reported the presence of oxide species on the deposit surfaces. Therefore, it is important to understand the operational parameters that lead to the formation of the oxides and their effect on the continuation of the $\mathrm{Nd}^{3+}$ reduction reaction to control the quality and quantity of $\mathrm{Nd}$.

Further, previous work on Nd electrodeposition has commonly been performed in modelled electrolyte systems in the presence of only $\mathrm{Nd}^{3+}$ ions. In realistic conditions, the powder obtained after the pre-processing of end-of-life magnets or Ni-MH batteries needs to first be dissolved in an appropriate solvent system to extract the metal ions into liquid media prior to the $\mathrm{Nd}$ electrodeposition. Such powder consists of various transition metal impurities and other REMs that may impact the recovery of $\mathrm{Nd}$ metal. Therefore, it is critical to investigate the effect of such impurities on Nd electrodeposition, to establish an efficient and selective recovery process. Significant research attention is also required towards investigating the $\mathrm{Nd}^{3+}$ solvation environment in the IL electrolytes, especially in the presence additives, co-solvents and impurities, as there is evidence, although limited, that this has a direct influence on the $\mathrm{Nd}^{3+}$ reduction capability and recovery efficiency. It is crucial to understand the effect of speciation on the electrodeposit composition as this may provide a new approach to recovering valuable $\mathrm{Nd}$ products through tuning the co-ordination environment. A favourable $\mathrm{Nd}^{3+}$ solvation structure may also increase the solubility of $\mathrm{Nd}^{3+}$, leading to increased cathodic current densities and thus higher quantity electrodeposits.

For ILs to be considered on a commercial scale for $\mathrm{Nd}$ recovery processes, it is essential to achieve low raw materials costs. The application of highly stable ILs that can be repeatedly used for longer durations is one way to effectively reduce the cost. Establishing efficient and effective IL recycling methodologies can also reduce the material cost by eliminating the requirement to frequently purchase new electrolytes. However, there is no information about the electrolyte lifetime (e.g., the maximum amount of charge that can be passed through the electrolyte before it must be discarded) or on recycling efforts for any of the ILs studied for Nd electrodeposition. Further, demonstration of Nd recovery efficiencies compatible or higher than the current state-of-the-art approaches will ultimately result in increased demand for the IL, and increased production volumes can decrease their bulk cost.

The need for $\mathrm{Nd}$ recovery, due to increasing demand and scarcity of supply, is essential for our current lifestyle and can only be achieved by more in-depth studies and exploration of a wider range of solvent systems and deposition parameters. In-depth studies in this area of research are also required to establish an economically favourable Nd electrodeposition methodology.

Author Contributions: Conceptualization, K.P., C.P.-G., J.M.P.; writing-original draft preparation: K.P.; writing—review and editing: K.P., L.S.-C., C.P.-G., J.M.P.; supervision: C.P.-G., J.M.P. All authors have read and agreed to the published version of the manuscript.

Funding: This work was funded by the Institute for Frontier Materials (Deakin University) Research program to lead innovative and transformative research in re-designing materials for a circular economy. This research received no external funding.

Conflicts of Interest: The authors declare no conflict of interest. 


\section{References}

1. Omodara, L.; Pitkäaho, S.; Turpeinen, E.M.; Saavalainen, P.; Oravisjärvi, K.; Keiski, R.L. Recycling and substitution of light rare earth elements, cerium, lanthanum, neodymium, and praseodymium from end-of-life applications-A review. J. Clean. Prod. 2019, 236, 117573. [CrossRef]

2. Swain, N.; Mishra, S. A review on the recovery and separation of rare earths and transition metals from secondary resources. J. Clean. Prod. 2019, 220, 884-898. [CrossRef]

3. Zhou, B.; Li, Z.; Chen, C. Global potential of rare earth resources and rare earth demand from clean technologies. Minerals 2017, 7, 203. [CrossRef]

4. Reilly, J.F. Mineral Commodity Summaries 2020; USGS: Reston, VA, USA, 2020.

5. Pell, R.S.; Wall, F.; Yan, X.; Bailey, G. Applying and advancing the economic resource scarcity potential (ESP) method for rare earth elements. Resour. Policy 2019, 62, 472-481. [CrossRef]

6. Binnemans, K.; Jones, P.T.; Blanpain, B.; Van Gerven, T.; Yang, Y.; Walton, A.; Buchert, M. Recycling of rare earths: A critical review. J. Clean. Prod. 2013, 51, 1-22. [CrossRef]

7. Binnemans, K.; Jones, P.T.; Müller, T.; Yurramendi, L. Rare Earths and the Balance Problem: How to Deal with Changing Markets? J. Sustain. Metall. 2018, 4, 126-146. [CrossRef]

8. Reimer, M.V.; Schenk-Mathes, H.Y.; Hoffmann, M.F.; Elwert, T. Recycling decisions in 2020, 2030, and 2040—when can substantial $\mathrm{NdFeB}$ extraction be expected in the EU? Metals 2018, 8, 867. [CrossRef]

9. Rollat, A.; Guyonnet, D.; Planchon, M.; Tuduri, J. Prospective analysis of the flows of certain rare earths in Europe at the 2020 horizon. Waste Manag. 2016, 49, 427-436. [CrossRef] [PubMed]

10. Mahmud, M.A.P.; Huda, N.; Farjana, S.H.; Lang, C. Comparative life cycle environmental impact analysis of lithium-ion (Liio) and nickel-metal hydride (nimh) batteries. Batteries 2019, 5, 22. [CrossRef]

11. Alonso, E.; Sherman, A.M.; Wallington, T.J.; Everson, M.P.; Field, F.R.; Roth, R.; Kirchain, R.E. Evaluating rare earth element availability: A case with revolutionary demand from clean technologies. Environ. Sci. Technol. 2012, 46, 3406-3414. [CrossRef] [PubMed]

12. Nassar, N.T.; Du, X.; Graedel, T.E. Criticality of the Rare Earth Elements. J. Ind. Ecol. 2015, 19, 1044-1054. [CrossRef]

13. Jha, M.K.; Kumari, A.; Panda, R.; Kumar, J.R.; Yoo, K.; Lee, J.Y. Review on hydrometallurgical recovery of rare earth metals. Hydrometallurgy 2016, 165, 2-26. [CrossRef]

14. Assefi, M.; Maroufi, S.; Yamauchi, Y.; Sahajwalla, V. Pyrometallurgical recycling of Li-ion, Ni-Cd and Ni-MH batteries: A minireview. Curr. Opin. Green Sustain. Chem. 2020, 24, 26-31. [CrossRef]

15. Firdaus, M.; Rhamdhani, M.A.; Durandet, Y.; Rankin, W.J.; McGregor, K. Review of High-Temperature Recovery of Rare Earth (Nd/Dy) from Magnet Waste. J. Sustain. Metall. 2016, 2, 276-295. [CrossRef]

16. Chen, J.P.; Lim, L.L. Recovery of precious metals by an electrochemical deposition method. Chemosphere 2005, 60, 1384-1392. [CrossRef]

17. Endres, F. Ionic liquids: Solvents for the electrodeposition of metals and semiconductors. ChemPhysChem 2002, 3, 144-154. [CrossRef]

18. Halli, P.; Heikkinen, J.J.; Elomaa, H.; Wilson, B.P.; Jokinen, V.; Yliniemi, K.; Franssila, S.; Lundström, M. Platinum Recovery from Industrial Process Solutions by Electrodeposition-Redox Replacement. ACS Sustain. Chem. Eng. 2018, 6, 14631-14640. [CrossRef]

19. Lindsay, S.J.; Welch, B.J. A Review: Understanding the Science and the Impacts of Impurities upon the Electrolytic Bath of Hall-Héroult Reduction Cells. J. Miner. Met. Mater. Soc. 2021, 73, 1196-1209. [CrossRef]

20. Lee, Y.J.; Lee, T.H.; Kim, D.Y.; Nersisyan, H.H.; Han, M.H.; Kang, K.S.; Bae, K.K.; Shin, Y.J.; Lee, J.H. Microstructural and corrosion characteristics of tantalum coatings prepared by molten salt electrodeposition. Surf. Coat. Technol. 2013, 235, 819-826. [CrossRef]

21. Izadpanah, S.M.; Aboutalebi, M.R.; Adeli, M. Molten salt electrodeposition of aluminum on mild steel: Effect of process parameters on surface morphology and corrosion properties. Mater. Res. Express 2021, 8, 046518. [CrossRef]

22. Abbott, A.P.; Frisch, G.; Ryder, K.S. Electroplating using ionic liquids. Annu. Rev. Mater. Res. 2013, 43, 335-358. [CrossRef]

23. Abbott, A.P.; Frisch, G.; Ryder, K.S. Metal complexation in ionic liquids. Annu. Rep. Prog. Chem.-Sect. A 2008, 104, 21-45. [CrossRef]

24. Abbott, A.P.; McKenzie, K.J. Application of ionic liquids to the electrodeposition of metals. Phys. Chem. Chem. Phys. 2006, 8 , 4265-4279. [CrossRef]

25. Bernasconi, R.; Panzeri, G.; Accogli, A.; Liberale, F.; Nobili, L.; Magagnin, L. Chapter 11—Electrodeposition from Deep Eutectic Solvents. In Progress and Developments in Ionic Liquids; IntechOpen: London, UK, 2017; pp. 235-261.

26. AliAkbari, R.; Marfavi, Y.; Kowsari, E.; Ramakrishna, S. Recent Studies on Ionic Liquids in Metal Recovery from E-Waste and Secondary Sources by Liquid-Liquid Extraction and Electrodeposition: A Review. Mater. Circ. Econ. 2020, 2, 10. [CrossRef]

27. Tunsu, C. Hydrometallurgy in the recycling of spent NdFeB permanent magnets. In Waste Electrical and Electronic Equipment Recycling: Aqueous Recovery Methods; Elsevier Ltd.: Amsterdam, The Netherlands, 2018; pp. 175-211. ISBN 9780081020579.

28. Erust, C.; Akcil, A.; Tuncuk, A.; Deveci, H.; Yazici, E.Y. A Multi-stage Process for Recovery of Neodymium (Nd) and Dysprosium (Dy) from Spent Hard Disc Drives (HDDs). Miner. Process. Extr. Metall. Rev. 2019, 42, 90-101. [CrossRef]

29. Meshram, P.; Pandey, B.D.; Mankhand, T.R. Process optimization and kinetics for leaching of rare earth metals from the spent Ni-metal hydride batteries. Waste Manag. 2016, 51, 196-203. [CrossRef] 
30. Pietrelli, L.; Bellomo, B.; Fontana, D.; Montereali, M.R. Rare earths recovery from NiMH spent batteries. Hydrometallurgy 2002, 66, 135-139. [CrossRef]

31. Parhi, P.K.; Sethy, T.R.; Rout, P.C.; Sarangi, K. Separation and recovery of neodymium and praseodymium from permanent magnet scrap through the hydrometallurgical route. Sep. Sci. Technol. 2016, 51, 2232-2241. [CrossRef]

32. Behera, S.S.; Parhi, P.K. Leaching kinetics study of neodymium from the scrap magnet using acetic acid. Sep. Purif. Technol. 2016, 160, 59-66. [CrossRef]

33. Meshram, P.; Somani, H.; Pandey, B.D.; Mankhand, T.R.; Deveci, H. Abhilash Two stage leaching process for selective metal extraction from spent nickel metal hydride batteries. J. Clean. Prod. 2017, 157, 322-332. [CrossRef]

34. Lee, C.H.; Yen, H.Y.; Liao, C.H.; Popuri, S.R.; Cadogan, E.I.; Hsu, C.J. Hydrometallurgical processing of Nd-Fe-B magnets for Nd purification. J. Mater. Cycles Waste Manag. 2017, 19, 102-110. [CrossRef]

35. Yoon, H.S.; Kim, C.J.; Chung, K.W.; Kim, S.D.; Lee, J.Y.; Kumar, J.R. Solvent extraction, separation and recovery of dysprosium (Dy) and neodymium $(\mathrm{Nd})$ from aqueous solutions: Waste recycling strategies for permanent magnet processing. Hydrometallurgy 2016, 165, 27-43. [CrossRef]

36. Ryu, H.Y.; Lee, J.H.; Kim, W.G.; Nersisyan, H.H.; Lee, G.G.; Jo, S.K.; Lee, H.H.; Hwang, I.S. Electrochemical behavior of Nd in its pyrometallurgical recovery from waste magnet. Rare Met. 2015, 34, 111-117. [CrossRef]

37. Öhl, J. Challenges in electrolysis of neodymium in chloride melts at $500{ }^{\circ} \mathrm{C}$. J. Appl. Electrochem. 2018, 48, 765-772. [CrossRef]

38. Tsubota, T.; Ohtaki, M.; Eguchi, K. Thermoelectric Properties of Chevrel-Type Sulfides AMo6S8 (A = Fe, Ni, Ag, Zn, Sn, Pb, Cu). J. Ceram. Soc. Jpn. 1999, 107, 697-701. [CrossRef]

39. Shirayama, S.; Okabe, T.H. Selective Extraction and Recovery of Nd and Dy from Nd-Fe-B Magnet Scrap by Utilizing Molten $\mathrm{MgCl}_{2}$. Metall. Mater. Trans. B 2018, 49, 1067-1077. [CrossRef]

40. Akahori, T.; Miyamoto, Y.; Saeki, T.; Okamoto, M.; Okabe, T.H. Optimum conditions for extracting rare earth metals from waste magnets by using molten magnesium. J. Alloys Compd. 2017, 703, 337-343. [CrossRef]

41. Bian, Y.Y.; Guo, S.Q.; Xu, Y.L.; Tang, K.; Lu, X.G.; Ding, W.Z. Recovery of rare earth elements from permanent magnet scraps by pyrometallurgical process. Rare Met. 2015, 239-248. [CrossRef]

42. Maroufi, S.; Khayyam Nekouei, R.; Sahajwalla, V. Thermal Isolation of Rare Earth Oxides from Nd-Fe-B Magnets Using Carbon from Waste Tyres. ACS Sustain. Chem. Eng. 2017, 5, 6201-6208. [CrossRef]

43. Maroufi, S.; Nekouei, R.K.; Hossain, R.; Assefi, M.; Sahajwalla, V. Recovery of Rare Earth (i.e., La, Ce, Nd, and Pr) Oxides from End-of-Life Ni-MH Battery via Thermal Isolation. ACS Sustain. Chem. Eng. 2018, 6, 11811-11818. [CrossRef]

44. Müller, T.; Friedrich, B. Development of a recycling process for nickel-metal hydride batteries. J. Power Sources 2006, 158, 1498-1509. [CrossRef]

45. Jiang, Y.; Deng, Y.; Bu, W. Pyrometallurgical Extraction of Valuable Elements in Ni-Metal Hydride Battery Electrode Materials. Metall. Mater. Trans. B Process. Metall. Mater. Process. Sci. 2015, 46, 2153-2157. [CrossRef]

46. Huang, C.; Liu, X.; Gao, Y.; Liu, S.; Li, B. Cathodic processes of neodymium(III) in LiF- $-\mathrm{NdF}_{3}-\mathrm{Nd}_{2} \mathrm{O}_{3}$ melts. Faraday Discuss. 2016, 190, 339-349. [CrossRef] [PubMed]

47. Tang, H.; Pesic, B. Electrochemistry and the mechanisms of nucleation and growth of neodymium during electroreduction from LiCl-KCl eutectic salts on Mo substrate. J. Nucl. Mater. 2015, 458, 37-44. [CrossRef]

48. Hamel, C.; Chamelot, P.; Taxil, P. Neodymium(III) cathodic processes in molten fluorides. Electrochim. Acta 2004, 49, 4467-4476. [CrossRef]

49. Novoselova, A.; Smolenski, V. Electrochemical behavior of neodymium compounds in molten chlorides. Electrochim. Acta 2013, 87, 657-662. [CrossRef]

50. Stefanidaki, E.; Hasiotis, C.; Kontoyannis, C. Electrodeposition of neodymium from LiF- $\mathrm{NdF}_{3}-\mathrm{Nd}_{2} \mathrm{O}_{3}$ melts. Electrochim. Acta 2001, 46, 2665-2670. [CrossRef]

51. Bourbos, E.; Karantonis, A.; Sygellou, L.; Paspaliaris, I.; Panias, D. Study of Nd electrodeposition from the aprotic organic solvent dimethyl sulfoxide. Metals 2018, 8, 803. [CrossRef]

52. MacFarlane, D.R.; Tachikawa, N.; Forsyth, M.; Pringle, J.M.; Howlett, P.C.; Elliott, G.D.; Davis, J.H.; Watanabe, M.; Patrice, S.; Austen, A.C. Energy applications of ionic liquids. Energy Environ. Sci. 2014, 7, 232-250. [CrossRef]

53. Xue, Z.; Qin, L.; Jiang, J.; Mu, T.; Gao, G. Thermal, electrochemical and radiolytic stabilities of ionic liquids. Phys. Chem. Chem. Phys. 2018, 20, 8382-8402. [CrossRef]

54. Endres, F.; Zein El Abedin, S. Air and water stable ionic liquids in physical chemistry. Phys. Chem. Chem. Phys. 2006, 8, 2101-2116. [CrossRef]

55. Kondo, H.; Matsumiya, M.; Tsunashima, K.; Kodama, S. Attempts to the electrodeposition of Nd from ionic liquids at elevated temperatures. Electrochim. Acta 2012, 66, 313-319. [CrossRef]

56. Sanchez-Cupido, L.; Pringle, J.M.; Siriwardana, A.L.; Unzurrunzaga, A.; Hilder, M.; Forsyth, M.; Pozo-Gonzalo, C. WaterFacilitated Electrodeposition of Neodymium in a Phosphonium-Based Ionic Liquid. J. Phys. Chem. Lett. 2019, 10, 289-294. [CrossRef] [PubMed]

57. Bourbos, E.; Giannopoulou, I.; Karantonis, A.; Paspaliaris, I.; Panias, D. Reduction of Light Rare Earths and a Proposed Process for Nd Electrorecovery Based on Ionic Liquids. J. Sustain. Metall. 2018, 4, 395-406. [CrossRef]

58. Matsumiya, M.; Ishii, M.; Kazama, R.; Kawakami, S. Electrochemical analyses of diffusion behaviors and nucleation mechanisms for neodymium complexes in [DEME][TFSA] ionic liquid. Electrochim. Acta 2014, 146, 371-377. [CrossRef] 
59. Matsumiya, M.; Kikuchi, Y.; Yamada, T.; Kawakami, S. Extraction of rare earth ions by tri-n-butylphosphate/phosphonium ionic liquids and the feasibility of recovery by direct electrodeposition. Sep. Purif. Technol. 2014, 130, 91-101. [CrossRef]

60. Krishna, G.M.; Rout, A.; Venkatesan, K.A. Voltammetric investigation of some lanthanides in neutral ligand-ionic liquid. J. Electroanal. Chem. 2020, 856, 113671. [CrossRef]

61. Bagri, P.; Luo, H.; Popovs, I.; Thapaliya, B.P.; Dehaudt, J.; Dai, S. Trimethyl phosphate based neutral ligand room temperature ionic liquids for electrodeposition of rare earth elements. Electrochem. Commun. 2018, 96, 88-92. [CrossRef]

62. Murakami, S.; Matsumiya, M.; Yamada, T.; Tsunashima, K. Extraction of Pr(III), Nd(III), and Dy(III) from HTFSA Aqueous Solution by TODGA/Phosphonium-Based Ionic Liquids. Solvent Extr. Ion Exch. 2016, 34, 172-187. [CrossRef]

63. Ishii, M.; Matsumiya, M.; Kawakami, S. Development of Recycling Process for Rare Earth Magnets by Electrodeposition Using Ionic Liquids Media. ECS Trans. 2012, 50, 549-560. [CrossRef]

64. Kondo, H.; Matsumiya, M.; Tsunashima, K.; Kodama, S. Investigation of Oxidation State of the Electrodeposited Neodymium Metal Related with the Water Content of Phosphonium Ionic Liquids. ECS Trans. 2013, 50, 529-538. [CrossRef]

65. Sanchez-Cupido, L.; Pringle, J.M.; Siriwardana, A.I.; Hilder, M.; Forsyth, M.; Pozo-Gonzalo, C. Correlating Electrochemical Behavior and Speciation in Neodymium Ionic Liquid Electrolyte Mixtures in the Presence of Water. ACS Sustain. Chem. Eng. 2020, 8, 14047-14057. [CrossRef]

66. Dong, Y. Effect of alkyl chain length on interfacial structure of imidazolium-based tetrafluoroborate ionic liquids on Au(100) electrodes. Mater. Res. Express 2020, 7, 075010. [CrossRef]

67. Li, H.; Endres, F.; Atkin, R. Effect of alkyl chain length and anion species on the interfacial nanostructure of ionic liquids at the $\mathrm{Au}(111)$-ionic liquid interface as a function of potential. Phys. Chem. Chem. Phys. 2013, 15, 14624-14633. [CrossRef]

68. Ota, H.; Matsumiya, M.; Sasaya, N.; Nishihata, K.; Tsunashima, K. Investigation of electrodeposition behavior for Nd(III) in [P2225][TFSA] ionic liquid by EQCM methods with elevated temperatures. Electrochim. Acta 2016, 222, 20-26. [CrossRef]

69. Razo-Negrete, M.; Ortega-Borges, R.; Zinovyeva, V.; Cannes, C.; Le Naour, C.; Trejo-Córdova, G.; Meas, Y. Comparison of the electrochemical behavior of some Rare Earth Elements in butyl methylpyrrolidinium dicyanamide ionic liquid. Int. J. Electrochem. Sci. 2019, 14, 10431-10447. [CrossRef]

70. Sanchez-Cupido, L.; Pringle, J.M.; Siriwardana, A.; Pozo-Gonzalo, C.; Forsyth, M. Electrochemistry of Neodymium in Phosphonium Ionic Liquids: The Influence of Cation, Water Content, and Mixed Anions. Aust. J. Chem. 2020, 73, $1080-1087$. [CrossRef]

71. Periyapperuma, K.; Pringle, J.M.; Sanchez-Cupido, L.; Forsyth, M.; Pozo-Gonzalo, C. Fluorine-free ionic liquid electrolytes for sustainable neodymium recovery using an electrochemical approach. Green Chem. 2021, 23, 3410-3419. [CrossRef]

72. Costa, S.P.F.; Azevedo, A.M.O.; Pinto, P.C.A.G.; Saraiva, M.L.M.F.S. Environmental Impact of Ionic Liquids: Recent Advances in (Eco)toxicology and (Bio)degradability. ChemSusChem 2017, 10, 2321-2347. [CrossRef]

73. Neuwald, I.J.; Zahn, D.; Knepper, T.P. Are (fluorinated) ionic liquids relevant environmental contaminants? High-resolution mass spectrometric screening for per- and polyfluoroalkyl substances in environmental water samples led to the detection of a fluorinated ionic liquid. Anal. Bioanal. Chem. 2020, 412, 4881-4892. [CrossRef]

74. Vieira, N.S.M.; Stolte, S.; Araújo, J.M.M.; Rebelo, L.P.N.; Pereiro, A.B.; Markiewicz, M. Acute Aquatic Toxicity and Biodegradability of Fluorinated Ionic Liquids. ACS Sustain. Chem. Eng. 2019, 7, 3733-3741. [CrossRef]

75. Swatloski, R.P.; Holbrey, J.D.; Rogers, R.D. Ionic liquids are not always green: Hydrolysis of 1-butyl-3- methylimidazolium hexafluorophosphate. Green Chem. 2003, 5, 361-363. [CrossRef]

76. Bubalo, M.C.; Radošević, K.; Redovniković, I.R.; Halambek, J.; Srček, V.G. A brief overview of the potential environmental hazards of ionic liquids. Ecotoxicol. Environ. Saf. 2014, 99, 1-12. [CrossRef]

77. MacFarlane, D.R.; Forsyth, S.A.; Golding, J.; Deacon, G.B. Ionic liquids based on imidazolium, ammonium and pyrrolidinium salts of the dicyanamide anion. Green Chem. 2002, 4, 444-448. [CrossRef]

78. Dutta, B.; Ruhela, R.; Yadav, M.; Singh, A.K.; Sahu, K.K.; Padmanabhan, N.P.H.; Chakravartty, J.K. Liquid-liquid extraction studies of gadolinium with N-methyl-N,N,N-trioctyl ammonium-bis-(2-ethylhexyl) phosphonate-Task specific ionic liquid. Sep. Purif. Technol. 2017, 175, 158-163. [CrossRef]

79. Zarrougui, R.; Mdimagh, R.; Raouafi, N. Highly efficient and eco-friendly extraction of neodymium using, undiluted and non-fluorinated ionic liquids. Direct electrochemical metal separation. Sep. Purif. Technol. 2017, 175, 87-98. [CrossRef]

80. Chen, L.; Sharifzadeh, M.; Mac Dowell, N.; Welton, T.; Shah, N.; Hallett, J.P. Inexpensive ionic liquids: [HSO $\left.{ }^{4}\right]^{-}$-based solvent production at bulk scale. Green Chem. 2014, 16, 3098-3106. [CrossRef]

81. Sousa, N.G.; Salgueira, J.F.S.; Sousa, C.P.; Campos, O.S.; Salazar-Banda, G.R.; Eguiluz, K.I.B.; de Lima-Neto, P.; Correia, A.N. Silver electrodeposition at room temperature protic ionic liquid 1-H-methylimidazolium hydrogen sulfate. J. Mol. Liq. 2020, 313, 113487. [CrossRef]

82. Zhang, Q.; Yu, X.; Hua, Y.; Xue, W. The effect of quaternary ammonium-based ionic liquids on copper electrodeposition from acidic sulfate electrolyte. J. Appl. Electrochem. 2015, 45, 79-86. [CrossRef]

83. Liu, T.; Vilar, R.; Eugénio, S.; Grondin, J.; Danten, Y. Electrodeposition of nanocrystalline copper thin films from 1-ethyl-3methylimidazolium ethylsulphate ionic liquid. J. Appl. Electrochem. 2014, 44, 189-198. [CrossRef] 